Send your letters to the editor, British Dental Journal, 64 Wimpole Street, London W1G 8YS or by email to bdj@bda.org

Priority will be given to letters less than 500 words long. Letters should be typed. Authors must sign the letter, which may be edited for reasons of space

\section{Maintenance fees}

Sir, there is a great deal of discussion about tuition and maintenance fees and the amount of debt that students are likely to incur by the time that they qualify. If times are hard for students in the UK, then spare a thought for those in the third world where poverty and civil unrest can cause students to give up their training in midstream due to lack of funds.

Part of the remit of the Christian Dental Fellowship is, not only to help support several dental missionaries abroad, but where funds allow, to assist dental students in the third world who would otherwise have to give up their studies. At present, the Christian Dental Fellowship is paying for the training of three dental students in Uganda.

\section{Sprawson}

Salisbury

doi: 10.1038/sj.bdj.4812051

\section{Omission}

Sir, in June 2004 the Faculty of General Dental Practitioners (UK) published a second and revised edition of its respected guidance, Selection Criteria for Dental Radiography.

Unfortunately, there is an omission in the credits which appear in the introductory pages, viii and ix. We do not give credit to Allan Thom and Keith Isaacson for their contribution of the orthodontic guidance.

We were highly appreciative of the assistance given to us by Allan Thom and Keith Isaacson, and by the British Orthodontic Society.

The error will be corrected in the first reprint of Selection Criteria. This is likely to be in spring 2005.

In the meantime, I would be grateful if I can extend our apologies for the omission through your pages.

I. Pocock

Faculty of General Dental Practitioners

By email

doi: 10.1038/sj.bdj.4812052

\section{Body of evidence}

Sir, the $B D J$ could easily contribute to the body of evidence, currently sparse, on the effect of CPD delivery on dentists' level of knowledge.

If the CPD programme in its present form was altered, simply by publishing in a similar format, the questions for the relevant article prior to the issue containing the educational information, then if scored similarly to the current scoring system, this baseline could be compared to the scores obtained for same questions after the relevant articles were published.

It would be interesting to observe any drop in the number of $100 \%$ scores that may or may not result.

Then we could start thinking about how new knowledge, if it is proven, impacts on practice.

\section{E. T. Taylor}

By email

\section{Professor Andrew Eder, Director of Eastman CPD and Dr Maurice Faigenblum, Lead for the BDJ Eastman CPD}

Programme, responds: Eastman CPD were delighted to receive your helpful comments. However, in the current design of the programme, many of the questions are article specific so it would not always be appropriate to publish the questions in advance as they may be taken out of context.

One of our colleagues at the Eastman Dental Institute has recently undertaken a study involving 400 of the 7,000 registered users of the BDJ Eastman $\mathrm{CPD}$ programme.

Some of the findings address the issues you have raised and it is intended that this data will be published shortly.

In the meantime, please rest assured that the programme is reviewed regularly with the BDJ and Nature Publishing and your comments will be considered further in this forum.

doi: 10.1038/sj.bdj.4812053

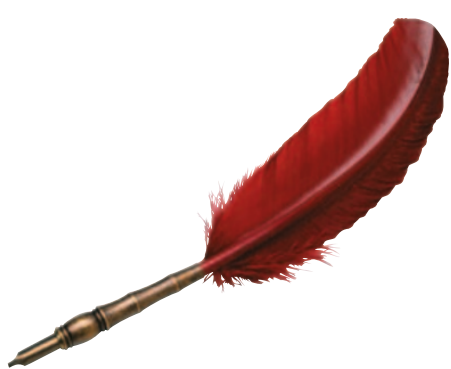

\section{Forgotten dentists}

Sir, in the 1930s dental disease was widespread in Britain; 90\% of school children required treatment, $40 \%$ of it radical. In three ordnance factories surveyed only $1 \%$ of workers were dentally fit.

The dental profession numbered 12,000, only half of whom were university trained.

The Dental Schools had too few students and teaching was poor. Britain was offered almost 1,000 well-trained dental graduates from Germany and Austria who were refugees from Nazi persecution.

The Home Office, using the Alien Acts of 1905, 1914, and 1919, saw Britain as a temporary port of call on the way to other countries.

With unemployment being high, the dental and medical professions wanted a closed shop and they also feared bettertrained competition.

By 1939 only some 314 were allowed onto the foreign list of the Dentists Register and the Home Office initially gave very few the right to practise.

As part of a PhD thesis, I am trying to reconstruct the history of this brave group of professionals, who despite the odds, succeeded in a foreign country which did not want them.

I am looking for as much detail about individual dentists as possible, including reminiscences of life histories from colleagues and family members. I can be contacted at jszamet@blueyonder.co.uk.

J. Zamet

By email

doi: 10.1038/sj.bdj.4812054

\section{Oration}

Sir, is anyone aware of an appropriate hymn, oration or quotation for the funeral of a dental surgeon or orthodontist?

M. Scott

By email

doi: 10.1038/sj.bdj.4812055 